Volume 4 Nomor 2, Juli-Desember 2020: hlm. 111-128.

Fakultas Hukum, Universitas Lampung,

Bandar Lampung, Lampung, Indonesia.

E-ISSN: 2598-3105 P-ISSN: 2723-2581

http://jurnal.fh.unila.ac.id/index.php/cepalo

\title{
PENEGAKAN HUKUM DALAM PENGADAAN BARANG DAN JASA PEMERINTAH OLEH KOMISI PENGAWAS PERSAINGAN USAHA (KPPU) DAN KOMISI PEMBERANTASAN KORUPSI (KPK)
}

\section{ENFORCEMENT IN GOVERNMENT'S PROCUREMENTS OF GOODS AND SERVICES BY KPPU: INDONESIAN COMPETITION COMMISSION AND KPK: CORRUPTION ERADICATION COMMISSION}

\author{
Adam Khafi Ferdinand ${ }^{1}$, Sunarto DM², Maya Shafira ${ }^{3}$
}

\footnotetext{
${ }^{1}$ Fakultas Hukum, Universitas Lampung, Email: adamkferdinand12@gmail.com

${ }^{2}$ Fakultas Hukum, Universitas Lampung, Email: mayashafira2@gmail.com

${ }^{3}$ Fakultas Hukum, Universitas Lampung, Email: sunarto54@fh.unila.ac.id
}

Submitted: June 24, 2020; Reviewed: July 15, 2020; Accepted: July 29, 2020

DOI: $10.25041 /$ cepalo.v4no2.2006

\begin{abstract}
Abstrak
Persekongkolan tender dan tindak pidana korupsi memiliki hubungan erat karena berkaitan dengan pengadaan barang dan jasa yang dilakukan pemerintah, karena sebagian atau seluruhnya pengadaan dibiayai dari APBN/APBD atau anggaran negara lainnya. Perbuatan dalam persekongkolan tender juga dapat dikategorikan sebagai perbuatan tindak pidana korupsi. Oleh karena itu, terdapat dua lembaga penegak hukum yang berwenang menindak para pelakunya, yakni KPPU dan KPK. Tujuan dari penulisan jurnal ini untuk mengetahui bagaimana upaya penegakan hukum dalam pengadaan barang dan jasa pemerintah yang dilakukan oleh KPPU dan KPK, serta apa saja faktor-faktor yang mempengaruhi proses penegakan hukumnya. Penelitian ini menggunakan metode penulisan hukum normatif yang didukung dengan data dan informasi dari wawancara/kuisioner. Sementara itu, pendekatan yang dilakukan yakni menggunakan pendekatan perundang-undangan (statue approach) dan pendekatan komparatif (comparative approach). Hasil dari penelitian ini menerangkan bahwa penegakan hukum dalam pengadaan barang dan jasa pemerintah yang dilakukan oleh KPPU terhadap perkara persekongkolan tender dilaksanakan berdasarkan Undang-Undang Anti Monopoli, Perkom No.1/2019 dan Perkom No.2/2010 (Pedoman Pasal 22). Sedangkan, penegakan hukum dalam pengadaan barang dan jasa pemerintah dilakukan oleh KPK terhadap perkara tindak pidana korupsi berdasarkan Undang-Undang Tipikor, UndangUndang KPK dan KUHAP. Kedua lembaga tersebut memang memiliki ruang lingkup dan kewenangannya masing-masing, namun keduanya juga memiliki kerjasama dalam hal pengawasan dan penegakan hukum dalam pengadaan barang dan jasa pemerintah yang tertuang dalam Memorandum of Understanding (MoU) antara KPPU dan KPK. Sementara itu, faktor-faktor yang mempengaruhi penegakan hukum dalam pengadaan barang dan jasa pemerintah yang dilakukan oleh KPPU dan KPK, antara lain faktor peraturan perundangundangan (substansi hukum), faktor penegak hukum, faktor sarana/fasilitas, faktor masyarakat dan faktor kebudayaan.
\end{abstract}


Kata Kunci: KPK, KPPU, Penegakan, Pengadaan.

\section{Abstract}

Conspiracy of tender and corruption are both have related in government's procurements of goods and services, because the procure partially or completely are being financed by $A P B N / A P B D$ or another state budgeter. The act in the conspiracy of tender also is categorized as an act of corruptions. Therefore, there are two law enforcement institutions which have the authority to punish the perpetrators, that are KPPU and KPK. The purpose from this journal is to find out about how the efforts in law enforcement on government's procurements of goods and services by KPPU and KPK, and what are the influence factors in the law enforcements process. This research is used with law normative method which is supported with data and information from interview or questionnaire. Futhermore, these article is using with statue approach and comparative approach. The results from this research are the law enforcement in government's procurements goods and services by KPPU on tender conspiracy case have implemented of based in Anti Monopoly Law, KPPU Law Number 1 of 2019 and KPPU Law Number 2 of 2010 (Guidelines of Article 22). Whereas, law enforcement in government's procurements goods and services by KPK on corruption case have implemented of based in Corruption Law, KPK Law and KUHAP. Both institutions have scope and authority for each other, however both of them have cooperation in terms of supervision and the law enforcement in government's procurements goods and services which is poured on Memorandum of Understanding (MoU) between KPPU and $K P K$. Other than that, there are many factors that influence the law enforcement in government's procurements goods and services by KPPU and KPK, there are law factor, law enforcer factor, tools/facilities factor, public factor and culture factor.

Keywords: KPK, KPPU, Enforcement, Procurement.

\section{A. Pendahuluan}

Pengadaan barang dan jasa merupakan upaya pemerintah selaku pengguna barang dan jasa guna mendapatkan barang/jasa yang diinginkan. Oleh karenanya, pemerintah perlu mengatur norma, prinsip-prinsip, metode serta proses pengadaan barang dan jasa. ${ }^{1}$ Dimana dibentuklah Keputusan Presiden Nomor 80 Tahun 2003 (Keppres No.80/2003) tentang Pedoman Pengadaan Barang/Jasa Pemerintah, yang dalam perkembangannya telah dilakukan perubahan sebanyak 7 (tujuh) kali. Pada mulanya pelaksanaan pengadaan barang dan jasa dilaksanakan secara konvensional. Namun dalam praktik pelaksanaannya terdapat banyak terjadi penyimpangan-penyimpangan dari prinsip dan etika serta ketentuan pengadaan barang/jasa pemerintah. Penyimpangan tersebut ada yang berwujud penyimpangan administrasi juga ada yang berupa tindakan korupsi yang merugikan keuangan atau perekonomian negara. Penyimpangan administrasi dalam pengadaan barang dan jasa pemerintah kerap terjadi dengan ditemukannya kesamaan berkas dokumen penawaran yang diajukan antara perusahaan yang satu dengan perusahaan yang lain pada saat pelelangan. Ada juga perbuatan dari panitia tender yang melakukan tindakan post bidding ataupun meloloskan

\footnotetext{
${ }^{1}$ Dwi Haryati, Anugrah Anditya, Richo Andi Wibowo, "PELAKSANAAN PENGADAAN BARANG/JASA SECARA ELEKTRONIK (E-PROCUREMENT) PADA PEMERINTAH KOTA YOGYAKARTA", Mimbar Hukum 23, no. 2 (2011): 328-342, 328, DOI: 10.22146/jmh.16192.
} 
perusahaan yang tidak memenuhi persyaratan pelelangan. ${ }^{2}$ Apabila penyimpanganpenyimpangan tersebut ditemukan unsur perbuatan melawan hukum seperti suap/gratifikasi bahkan berpotensi merugikan keuangan negara, hal tersebut dapat dikategorikan sebagai tindak pidana korupsi.

Memperhatikan berbagai penyimpangan tersebut serta selaras dengan kemajuan ilmu dan teknologi, maka pelaksanaan pengadaan barang dan jasa saat ini telah dilakukan melalui sarana internet/elektronik atau biasa yang dikenal dengan E-Procurement. Amanat pelaksanaan pengadaan barang dan jasa secara elektronik tersebut telah tercantum pada Peraturan Presiden Nomor 54 Tahun 2010 (Perpres No. 54/2010). Menurut Pasal 106 Perpres No.54/2010, pengadaan barang/jasa pemerintah dapat dilakukan secara elektronik dengan cara e-tendering atau e-purchasing. ${ }^{3}$ Guna melakukan penyempurnaan regulasi di bidang pengadaan barang dan jasa pemerintah, dirumuskan aturan terbaru oleh Lembaga Kebijakan Pengadaan Barang/Jasa Pemerintah (LKPP) dimana akhirnya Perpres No.54/2010 diganti dengan Peraturan Presiden Nomor 16 Tahun 2018 tentang Pengadaan Barang/Jasa Pemerintah (Perpres No. 16/2018). Perpres No.16/2018 ini dibuat lebih sederhana, mudah dikontrol dan diawasi sehingga diharapkan dapat mempercepat dan mempermudah pelaksanaan pengadaan barang dan jasa pemerintah. ${ }^{4}$

Peraturan mengenai pengadaan barang dan jasa pemerintah memang sudah beberapa kali diubah dan pelaksanaanya pun saat ini sudah menerapkan sistem elektronik (e-procurement). Namun nyatanya sampai sekarang tetap saja berbagai macam penyimpangan dan juga praktik Korupsi, Kolusi dan Nepotisme (KKN) yang dilakukan secara manual kerap kali terjadi dengan berbagai macam modifikasi. Hal tersebut disebabkan oleh perbuatan suap menyuap dan gratifikasi yang masih lumrah terjadi sehingga proses pelelangan kerap terpengaruh praktik kotor tersebut walaupun pelelangan dilakukan secara elektronik. Bentuk KKN dalam pengadaan barang dan jasa pemerintah biasanya dapat terindikasi dengan adanya persekongkolan dalam pelaksanaan tender pengadaan barang dan jasa yang dilakukan oleh antara para pelaku usaha maupun antara pelaku usaha bersama-sama dengan panitia pengadaan (panitia tender) dengan tujuan mengatur pemenang lelang/tender pengadaan. Praktik persekongkolan tender sendiri dapat mengakibatkan proses lelang/tender berlangsung tidak adil, dapat merugikan panitia tender ataupun peserta tender yang memiliki itikad baik, bahkan praktik tersebut dapat mengarah ke persaingan tidak sehat.

Sejak Tahun 2000 sampai Tahun 2020, kasus persekongkolan tender atau perkara pelanggaran terhadap Pasal 22 Undang-Undang Nomor 5 Tahun 1999 tentang Larangan Praktik Monopoli dan Persaingan Usaha Tidak Sehat (UU No.5/1999 atau UU Anti Monopoli), masih tetap menjadi kasus terbesar yang ditangani oleh Komisi Pengawas Persaingan Usaha (KPPU) yakni sebesar $67 \%$ dengan 235 perkara. ${ }^{5}$ Kasus-kasus tersebut hampir seluruhnya berkaitan dengan pengadaan barang dan jasa yang dilakukan pemerintah, baik pemerintah pusat maupun pemerintah daerah. Penyimpangan dari praktik persekongkolan tender dalam pengadaan barang dan jasa juga berimplikasi dengan timbulnya dampak lain berupa merugikan keuangan negara akibat praktik tender yang koruptif. Menurut data dari Indonesia Corruption Watch (ICW), disepanjang Tahun 2017 sektor pengadaan

\footnotetext{
${ }^{2}$ Dalam Penjelasan Pasal 79 ayat (2) Perpres No.54/2010, tindakan post bidding yaitu tindakan mengubah, menambah, mengganti dan/atau mengurangi Dokumen Pengadaan dan/atau Dokumen Penawaran setelah batas akhir pemasukan penawaran.

3 Purnomo Edy Mulyono, "ANALISIS PELAKSANAAN PENGADAAN BARANG/JASA SECARA ELEKTRONIK PADA PEMERINTAH KABUPATEN GRESIK”, Airlangga Development Journal 1, no. 1 (2017): 32-42, 37, DOI: 10.20473/adj.v1i1.18010.

https://jdih.lkpp.go.id/news/14/siaran-pers-peraturan-presiden-nomor-16-tahun-2018-tentang-pengadaanbarangjasa-pemerintah, diakses pada 31 Mei 2020, 12.36 WIB.

${ }^{5} \mathrm{http} / / /$ putusan.kppu.go.id/, diakses pada tanggal 8 September 2020, 19.40 WIB
} 
barang dan jasa merupakan wilayah yang rentan akan korupsi. Terdapat 84 kasus yang diproses hukum dengan kerugian negara mencapai Rp1,02 Triliun. Hal ini menunjukan bahwa sektor pelayanan publik (pengadaan barang dan jasa) sangat rentan untuk dikorupsi. ${ }^{6}$

Berdasarkan perhitungan Komisi Pemberantasan Korupsi (KPK), kasus-kasus di sektor pengadaan barang dan jasa telah mencapai jumlah kerugian negara hampir 1 Triliun rupiah. Data survey dari Indonesia Procurement Watch (IPW) pun memperlihatkan bahwa sekitar 93\% pengusaha melakukan suap/gratifikasi guna memenangkan tender proyek pengadaan barang dan jasa. Nilai proyek sebesar 12,35 Triliun rupiah dari 97 perkara tender yang merupakan gabungan proyek swasta maupun proyek pemerintah seperti Badan Usaha Milik Negara (BUMN) yang anggaranya berasal dari Anggaran Pendapatan dan Belanja Negara (APBN), dan Anggaran Pendapatan dan Belanja Daerah (APBD). Dari jumlah tersebut, setidaknya telah terbukti terjadi persekongkolan sebesar 8,6 Triliun . ${ }^{7}$ Persekongkolan tender dan tindak pidana korupsi memang memiliki hubungan erat karena berkaitan dengan pengadaan barang dan jasa yang dilakukan pemerintah. Pengadaan yang dilakukan pemerintah tentunya sebagian atau seluruhnya dibiayai dari APBN/APBD atau anggaran negara lainnya. Perbuatan-perbuatan dalam persekongkolan tender juga dapat dikategorikan sebagai perbuatan tindak pidana korupsi. Oleh karena itu, terdapat dua lembaga penegak hukum yang berwenang menindak para pelakunya, yakni KPPU dan KPK.

Berdasarkan uraian latar belakang di atas, maka permasalahan yang akan dibahas adalah bagaimana upaya penegakan hukum dalam pengadaan barang dan jasa pemerintah yang dilakukan oleh KPPU dan KPK? Apa saja faktor-faktor yang mempengaruhi penegakan hukum dalam pengadaan barang dan jasa pemerintah yang dilakukan oleh KPPU dan KPK? Penelitian ini menggunakan metode penulisan hukum normatif yaitu metode menggunakan metode kepustakaan yang terdiri dari bahan hukum sekunder dan peraturan perundangundangan yang berkaitan dengan isu-isu hukum tersebut, kemudian didukung dengan data dan informasi dari wawancara/kuisioner dengan narasumber serta bahan-bahan sekunder lainnya yang berkaitan dengan permasalahan yang diteliti. Objek kajian dari penelitian ini yaitu penegakan hukum yang dilakukan Komisi Pengawas Persaingan Usaha (KPPU) dan Komisi Pemberantasan Korupsi (KPK). Sementara itu, pendekatan yang dilakukan menggunakan pendekatan perundang-undangan (statue approach) dan pendekatan komparatif (comparative approach).

\section{B. Pembahasan}

\section{Upaya Penegakan Hukum dalam Pengadaan Barang dan Jasa Pemerintah yang dilakukan Oleh KPPU dan KPK}

Menurut Satjipto Raharjo penegakan hukum merupakan suatu proses untuk mewujudkan keinginan-keinginan hukum menjadi kenyataan. ${ }^{8}$ Upaya-upaya penegakan hukum dilaksanakan agar dapat dijalankan sebagaimana mestinya, termasuk upaya penegakan hukum di sektor pengadaan barang dan jasa pemerintah. Permasalahan berupa penyimpanganpenyimpangan dalam pengadaan barang dan jasa pemerintah memang sudah menjadi lingkup kewenangan dari KPPU dan KPK. Oleh karenanya, terlebih dahulu penulis akan menguraikan dasar aturan hukum dari kedua lembaga tersebut dan hubungan antar keduanya dalam menangani perkara persekongkolan tender dan tindak pidana korupsi dalam pengadaan barang dan jasa pemerintah.

\footnotetext{
${ }^{6}$ https://news.detik.com/berita/d-3885311/icw-korupsi-pengadaan-barang-2017-meningkat, diakses pada 31 Mei 2020, 12.50 WIB

${ }^{7}$ Deputi Penelitian dan Pengembangan KPK, Laporan Hasil: Kajian Pencegahan Korupsi Pada Pengadaan Barang dan Jasa Pemerintah, (Jakarta: KPK, 2014), 9

${ }^{8}$ Satjipto Raharjo, Penegakan Hukum Sebagai Tinjauan Sosiologis. (Yogyakarta: Genta Publishing, 2009), 25.
} 


\section{a. Komisi Pengawas Persaingan Usaha (KPPU)}

KPPU merupakan lembaga independen yang telah ditunjuk oleh Undang-Undang Nomor 5 Tahun 1999 tentang Larangan Praktik Monopoli dan Persaingan Usaha Tidak Sehat (UU Anti Monopoli). KPPU yang ada sekarang ini dibentuk berdasarkan Keputusan Presiden Republik Indonesia Nomor 75 Tahun $1999,{ }^{9}$ namun Keppres ini kemudian terakhir kali diubah menjadi Peraturan Presiden (Perpres) Nomor 80 Tahun 2008 tentang Komisi Pengawas Persaingan Usaha (KPPU). Pembentukan ini didasarkan pada Pasal 30 ayat (1) dan Pasal 34 UU Anti Monopoli. KPPU sebagai institusi yang diberi mandat untuk mengawasi dan menegakkan pelaksanaan atas UU Anti Monopoli.

KPPU merupakan lembaga negara komplementer (state auxiliary organ) jika dilihat dalam konteks ketatanegaraan. ${ }^{10}$ Sebagai suatu organ khusus, KPPU memiliki tugas ganda, dimana KPPU memiliki tugas untuk menciptakan ketertiban dalam persaingan usaha, KPPU juga berperan dalam menciptakan dan memelihara iklim persaingan usaha yang kondusif. ${ }^{11}$ Selain itu juga, KPPU memiliki fungsi dan kewenangan penegakan hukum khususnya hukum persaingan usaha. Kewenangan tersebut diatur dalam Pasal 36 dan Pasal 47 UU Anti Monopoli. Dimana KPPU berwenang untuk melakukan penyelidikan terhadap dugaan adanya persaingan usaha tidak sehat. ${ }^{12}$ KPPU juga berwenang untuk memanggil saksi-saksi maupun menilai dokumen dan alat bukti lainnya hingga memutuskan dan menjatuhkan sanksi kepada pelaku usaha yang melakukan pelanggaran persaingan usaha.

Adapun sumber KPPU untuk melakukan pemeriksaan terhadap pelaku usaha berasal dari adanya laporan atau atas dasar inisiatif dari KPPU sendiri. Tata cara penanganan perkara praktik monopoli dan persaingan usaha tidak sehat yang dilakukan oleh KPPU mengacu pada Peraturan Komisi Pengawas Persaingan Usaha Nomor 1 Tahun 2010 (Perkom No.1/2010), namun Perkom tersebut sudah tidak berlaku lagi dan diubah menjadi Perkom Nomor 1 Tahun 2019 (Perkom No.1/2019). Dalam Pasal 2 Perkom No.1/2019 dinyatakan sumber perkara di KPPU terdiri dari Laporan dan Inisiatif. ${ }^{13}$ Terdapat beberapa tahapan dalam proses suatu perkara di KPPU yang dapat diklasifikasi sebagai berikut:

1) Tahap pengumpulan dugaan pelanggaran (laporan atau inisiatif),

2) Tahap penyelidikan (investigasi);

3) Tahap pemeriksaan pendahuluan;

4) Tahap pemeriksaan lanjutan; dan

5) Tahap penjatuhan dan eksekusi putusan.

Sama seperti perkara persaingan usaha lainnya, dalam melaksanakan penegakan hukum perkara persekongkolan tender, KPPU juga mengacu pada Perkom No.1/2019. Dalam mengidentifikasi perkara persekongkolan tender, KPPU biasanya menggunakan pendekatan rule of reason. Hal ini karena dalam Pasal 22 UU Anti Monopoli terdapat unsur “....sehingga dapat mengakibatkan terjadinya persaingan usaha tidak sehat”. KPPU akan menganalisis

\footnotetext{
${ }^{9}$ Rosdalina Bukido dan Laila F. Bamatraf, "PERANAN KOMISI PENGAWAS PERSAINGAN USAHA (KPPU) DALAM MENEGAKAN UNDANG-UNDANG NOMOR 5 TAHUN 1999 TENTANG LARANGAN PRAKTIK MONOPOLI DAN PERSAINGAN USAHA TIDAK SEHAT', Jurnal Ilmiah Al-Syir'ah 15, no. 1 (2017): 56-73, 58

${ }^{10}$ Rilda Murniati, Hukum Persaingan Usaha (Bandar Lampung: Justice Publisher, 2014), 145

${ }^{11}$ Apectriyas Zihaningrum dan Munawar Kholil, "PENEGAKAN HUKUM PERSEKONGKOLAN TENDER BERDASARKAN UNDANG-UNDANG NOMOR 5 TAHUN 1999 TENTANG LARANGAN PRAKTIK MONOPOLI DAN PERSAINGAN USAHA TIDAK SEHAT", Privat Law 4, no. 1 (2016):107-116, 80

${ }^{12}$ Wisny, "PENERAPAN SANKSI ADMINISTRATIF OLEH KOMISI PENGAWAS PERSAINGAN USAHA (KPPU) TERHADAP PELAKU USAHA YANG MELAKUKAN PERSEKONGKOLAN DALAM TENDER", Pakuan Law Review 1, no. 2 (2015): 359-381, 369-370, DOI: 10.33751/palar.v2i2.941.

${ }_{13}$ Pasal 2 Peraturan Komisi Pengawas Persaingan Usaha No. 1 Tahun 2019 tentang Tata Cara Penanganan Perkara Praktik Monopoli dan Persaingan Usaha Tidak Sehat.
} 
dampak negatif atau akibat yang ditimbulkan dari persekongkolan. ${ }^{14}$ Rule of reason sendiri merupakan suatu pendekatan dengan melakukan analisis terhadap pasar beserta dampaknya terhadap persaingan, dimana dampak dari perbuatan pelaku usaha tersebut dinilai terlebih dahulu sebelum dinyatakan melanggar undang-undang. ${ }^{15}$

Khusus perkara persekongkolan tender, KPPU juga memiliki pedoman yang diatur dalam Peraturan Komisi Pengawas Persaingan Usaha Nomor 2 Tahun 2010 (Perkom No.2/2010) tentang Pedoman Pasal 22 UU Anti Monopoli tentang Larangan Persekongkolan dalam Tender (Pedoman Pasal 22). Pedoman tersebut dibuat untuk memfokuskan guna memberikan pengertian yang jelas, cakupan serta batasan ketentuan larangan persekongkolan tender. Pedoman juga ditujukan baik untuk para pelaku usaha maupun stakeholders lainnya agar mendapat dasar pemahaman dan arah yang jelas pelaksanaan Pasal 22 UU Anti Monopoli. Pedoman juga dibuat secara sederhana dan jelas yang terdiri dari tujuan dan cakupan pedoman, pasal terkait dengan persekongkolan tender, jenis persekongkolan tender hingga aturan sanksi yang dapat dijatuhkan KPPU kepada pelaku persekongkolan tender. Walaupun Perkom No. 2/2010 memberikan penjelasan ketentuan persekongkolan tender, namun demikian dalam proses penegakan hukum UU Anti Monopoli tetap mendahulukan pandangan dan putusan komisi serta tidak hanya terbatas pada pedoman saja.

\section{b. Komisi Pemberantasan Korupsi (KPK)}

Berbeda dengan KPPU, KPK merupakan suatu lembaga negara yang memiliki fungsi dan wewenang dalam pemberantasan dan pencegahan tindak pidana korupsi di Indonesia. ${ }^{16} \mathrm{KPK}$ dibentuk sesuai dengan amanat yang terdapat dalam Pasal 43 ayat (1) Undang-Undang Nomor 31 Tahun 1999 sebagaimana telah diubah dengan Undang-Undang Nomor 20 Tahun 2001 tentang Pemberantasan Tindak Pidana Korupsi (UU Tipikor). Atas dasar amanat tersebut, pada tanggal 27 Desember 2002 disahkanlah Undang-Undang Nomor 30 Tahun 2002 (UU No.30/2002) tentang KPK. Saat isni UU No.30/2002 telah mengalami perubahan kedua menjadi Undang-Undang Nomor 19 Tahun 2019 (UU No.19/2019) atau dikenal dengan UU KPK. UU KPK yang terbaru ini mulai berlaku setelah disahkan oleh DPR dan Pemerintah pada tanggal 17 September 2019. ${ }^{17}$

Ketika melaksanakan tugasnya, KPK harus memiliki lima acuan sebagai pedoman, antara lain: kepastian dalam melaksanakan pedoman, transparan, memiliki sifat yang akuntabilitas, mengutamakan kepentingan publik, dan proporsionalitas. KPK memiliki tanggung jawab yang besar kepada masyarakat luas dan harus memberikan laporannya secara terbuka, lengkap, berkala kepada Lembaga Eksekutif (dalam hal ini Presiden), Legislatif (dalam hal ini DPR), dan BPK. ${ }^{18} \mathrm{KPK}$ memiliki dasar hukum dalam proses penanganan perkara tindak pidana korupsi baik pada tahap penyelidikan, tahap penyidikan hingga tahap penuntutan yang dilakukan berdasarkan hukum acara pidana yang berlaku, yakni Undang-Undang Nomor 08 Tahun 1981 tentang Kitab Undang-Undang Hukum Acara Pidana (KUHAP) dan UU

\footnotetext{
14 Rilda Murniati, Op.Cit., 147

${ }^{15}$ Andi Fahmi Lubis, et al., Hukum Persaingan Usaha, ed.2, (Jakarta: KPPU, 2017), 89

${ }^{16}$ Muhammad Habibi, "INDEPENDENSI KEWENANGAN KOMISI PEMBERANTASAN KORUPSI PASCA PERUBAHAN UNDANG-UNDANG NOMOR 30 TAHUN 2002 TENTANG KOMISI PEMBERANTASAN KORUPSI”, Jurnal Cepalo 4, no. 1 (2020): 41-51, 42, DOI: 10.25041/cepalo.v4no1.1962.

${ }^{17}$ https://news.detik.com /berita/d-4748948/uu-kpk-baru-berlaku-ini-pasal-pasal-yang-mulai-aktif, diakses pada Selasa, 14 April 2020, 15.33 WIB.

18 Mahardika dan Firman Wijaya, "KAJIAN YURIDIS FUNGSI PENCEGAHAN KOMISI PEMBERANTASAN KORUPSI DALAM PEMBERANTASAN TINDAK PIDANA KORUPSI PENGADAAN BARANG DAN JASA SECARA ELEKTRONIK DI PROVINSI DKI JAKARTA”, Jurnal Hukum Adigama 1, no. 2 (2018): 1-25, 6, DOI: 10.24912/adigama.v1i2.2925.
} 
Tipikor. ${ }^{19}$ UU KPK berperan sebagai ketentuan bersifat khusus mengenai hukum acara peradilan tindak pidana korupsi yang dilakukan oleh KPK. Sedangkan KUHAP merupakan ketentuan yang bersifat umum dalam hukum acara peradilan pidana di peradilan umum.

Dalam pelaksanaannya, UU Tipikor, UU KPK dan KUHAP memiliki ketentuan yang saling melengkapi. Hal ini ditegaskan dalam Pasal 26 UU Tipikor, Pasal 38 dan Pasal 62 UU KPK. Dari ketiga ketentuan tersebut, menandakan bahwa berlaku asas hukum lex specialis derogat legi generalis. Dimana UU Tipikor dan UU KPK sebagai ketentuan khusus (lex specialis), sedangkan KUHAP sebagai ketentuan umum (lex generalis). Mengenai tugas KPK, UU KPK mengaturnya di dalam Pasal 6. Dimana KPK berwenang untuk melakukan pencegahan dan pemberantasan (penyelidikan, penyidikan dan penuntutan) terhadap tindak pidana korupsi. KPK juga berwenang untuk melakukan koordinasi dan supervisi dengan instansi/lembaga penegak hukum tindak pidana korupsi lainnya serta melaksanakan penetapan hakim dan putusan pengadilan yang telah memperoleh kekuatan hukum tetap. ${ }^{20}$ Penjelasan lebih lanjut dari wewenang KPK tersebut, diatur lebih jelas pada pasal-pasal berikutnya, yakni pada Pasal 7 sampai dengan Pasal 13 UU KPK.

Mengenai proses penyelidikan, KPK melakukan penyelidikan berdasarkan informasi/laporan yang diterima maupun diketahui langsung oleh penyelidik/penyidik. Selain itu, penyelidikan KPK juga dapat dilakukan dengan adanya laporan polisi ataupun dari berita acara pemeriksaan. Terdapat 2 (dua) macam penyelidikan yang dikenal dalam penanganan perkara di KPK yakni Penyelidikan Terbuka dan Penyelidikan Tertutup (seperti penyadapan dan operasi tangkap tangan). ${ }^{21}$ Pemeriksaan KPK pada tahap penyelidikan dilakukan untuk mengetahui adanya perbuatan tindak pidana korupsi yang dilakukan oleh seseorang/korporasi dengan terdapat bukti yang cukup sehingga memenuhi syarat pelaku sebagaimana diatur dalam Pasal 11 UU KPK. Kemudian pada tahap penyidikan, KPK akan melakukan pemeriksaan terhadap syarat-syarat pembuktian berdasarkan hukum acara pidana, melakukan pembuktian terhadap tersangka, melakukan upaya paksa (penangkapan, penahanan, penyitaan maupun penggeledahan), menggabungkan beberapa perkara (jika perlu) serta melaporkan dan menindaklanjuti jika ditemukan adanya tindak pidana pencucian uang (TPPU). Penyidik KPK juga dapat meminta bantuan kepada instansi lain yang melibatkan Badan Pemeriksa Keuangan (BPK) atau Badan Pengawas dan Pembangunan (BPKP) guna menghitung adanya jumlah kerugian negara yang ditimbulkan akibat perbuatan si pelaku. ${ }^{22}$

Selama melaksanakan tugasnya pada tahap penyelidikan dan penyidikan, KPK berwenang untuk meminta bantuan penangkapan, penahanan, penggeledahan dan penyitaan kepada instansi lain, pencekalan ke luar negeri, meminta keterangan keadaan keuangan pelaku, memblokir rekening, memberhentikan jabatan sementara, meminta data kekayaan beserta pajaknya, meminta hentikan maupun tunda transaksi keuangan, meminta bantuan pencairan orang/aset serta dapat melakukan penyadapan (walaupun saat ini harus melalui izin dewan pengawas terlebih dahulu). ${ }^{23}$ Permasalahan persekongkolan tender dan tindak pidana korupsi dalam pengadaan barang dan jasa pemerintah tentunya sudah menjadi ruang lingkup kewenangan bagi KPPU dan KPK. Dimana KPPU menindak para pelaku ke dalam perkara persekongkolan tender sebagaimana diatur dalam UU Anti Monopoli. Sedangkan KPK

\footnotetext{
${ }^{19}$ Pasal 39 ayat (1) UU No. 30 Tahun 2002 tentang Komisi Pemberantasan Korupsi, LN No. 137 Thn. 1999, TLN No. 4250.

${ }^{20}$ Pasal 6 ayat (1) UU No. 30 Tahun 2002 tentang Komisi Pemberantasan Korupsi, LN No. 137 Thn. 1999, TLN No. 4250.

${ }^{21}$ Pusat Edukasi Antikorupsi (KPK), Modul Materi Tindak Pidana Korupsi (Jakarta: Komisi Pemberantasan Korupsi, 2020), 48.

${ }^{22}$ Yayan Indriana, "PENGEMBALIAN GANTI RUGI KEUANGAN NEGARA PADA PERKARA TINDAK PIDANA KORUPSI”, Jurnal Cepalo 2, no. 2 (2018): 121-128, 125, DOI: 10.25041/cepalo.v2no2.1769.

${ }^{23}$ Pasal 12 ayat (2) Undang-Undang Republik Indonesia Nomor 19 Tahun 2019 Tentang Perubahan Kedua Atas Undang-Undang Nomor 30 Tahun 2002 Tentang Komisi Pemberantasan Tindak Pidana Korupsi.
} 
menindak para pelaku tindak pidana korupsi dalam pengadaan barang dan jasa pemerintah sebagaimana diatur dalam UU Tipikor. Kedua lembaga tersebut memiliki wewenangnya masing-masing. Khusus terhadap perkara persekongkolan tender yang terindikasi tindak pidana korupsi, keduanya dapat melakukan penegakan hukum. Membahas mengenai praktik persekongkolan tender, persekongkolan sendiri memiliki 3 (tiga) bentuk persekongkolan yakni:

1) Persekongkolan Horizontal, persekongkolan yang dilakukan antar pelaku usaha;

2) Persekongkolan Vertikal, persekongkolan yang dilakukan pelaku usaha dengan panitia tender/lelang; dan

3) Persekongkolan Gabungan (Horizontal \& Vertikal), persekongkolan yang dilakukan antar pelaku usaha dan panitia tender/lelang. ${ }^{24}$

Persekongkolan tender yang terindikasi tindak pidana korupsi dapat ditemukan dalam persekongkolan tender vertikal maupun gabungan (horizontal \& vertikal), karena di dalamnya biasanya terdapat perbuatan $\mathrm{KKN}$ yang menyebabkan persaingan tidak sehat bahkan berpotensi merugikan keuangan negara. PPU memiliki kewenangan untuk menindak para pelaku dari ketiga bentuk persekongkolan tersebut. Namun sayangnya, KPPU tidak memiliki wewenang untuk menjatuhkan sanksi kepada panitia tender yang terlibat melakukan persekongkolan. Hal tersebut membuat KPPU memiliki kewenangan yang timpang dalam mengatasi permasalahan persekongkolan tender.

Untuk mengatasi hal tersebut, KPPU dapat melakukan kerja sama dengan lembaga penegak hukum lainnya, salah satunya dengan KPK. KPK dapat menindak pelaku yang terlibat dalam persekongkolan tender apabila terdapat indikasi tindak pidana korupsi. Terutama dalam persekongkolan tender vertikal dan gabungan. Mengingat, berdasarkan kedua bentuk persekongkolan tersebut terdapat keterlibatan panitia tender/pelelangan yang merupakan unsur penyelenggara negara/pegawai negeri sebagaimana UU Tipikor. Hal tersebut juga menjadi kewenangan KPK yang diatur dalam Pasal 11 UU KPK. Di bawah dapat dilihat lingkup kewenangan KPK dalam menangani perkara persekongkolan tender (vertikal dan gabungan) dalam pengadaan barang dan jasa pemerintah:

Gambar 2: Lingkup Kewenangan KPK dalam Persekongkolan Tender Vertikal dan Gabungan

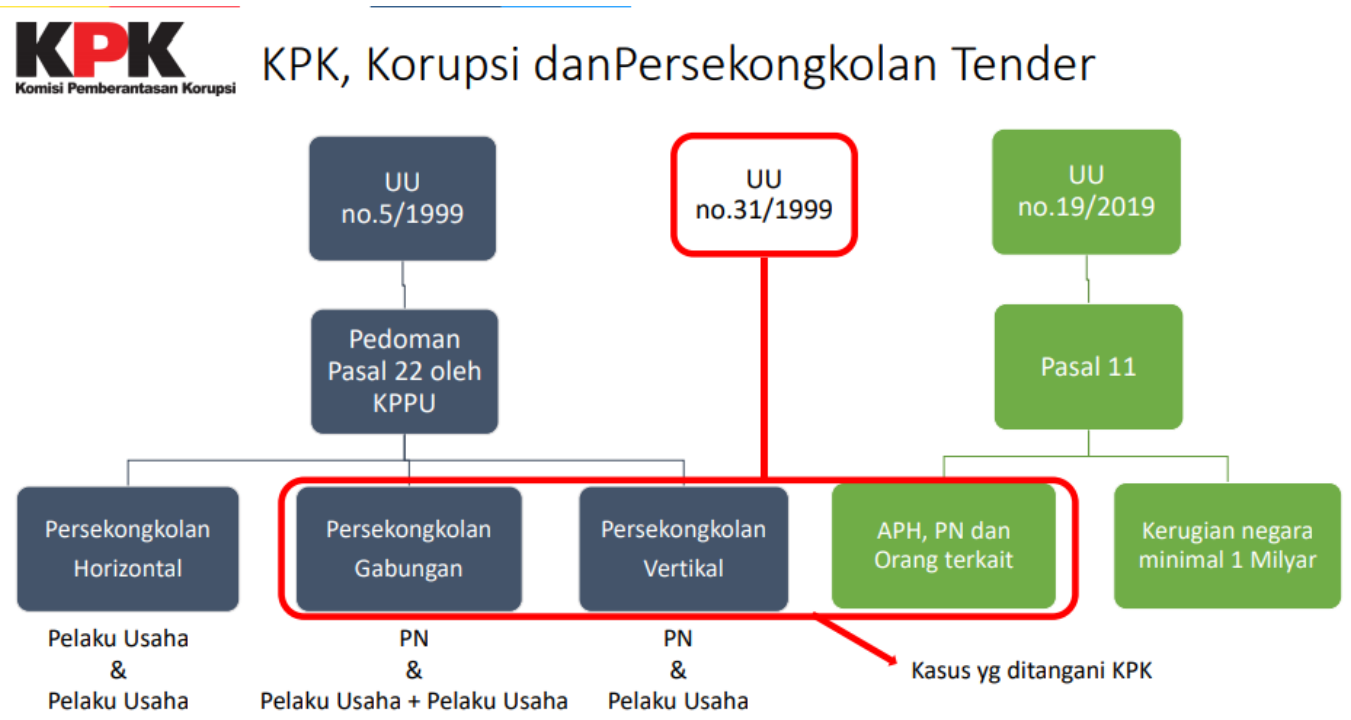

Sumber: Diskusi Publik Bersama KPPU \& KPK ${ }^{25}$

\footnotetext{
${ }^{24}$ Asmah, "PENERAPAN SANKSI DENDA TERHADAP KASUS PERSEKONGKOLAN TENDER JALAN NASIONAL", Jurnal Yudisial 12, no. 2 (2019): 197-214, 203, DOI: /10.29123/jy.v12i2.280.
} 
Mengacu pada gambar di atas, terhadap persekongkolan gabungan dan vertikal, KPK memiliki wewenang untuk menangani perkara tersebut karena terdapat keterlibatan Aparat Penegak Hukum (APH)/Penyelenggara Negara dan orang-orang yang terkait sebagaimana diatur dalam UU Tipikor dan UU KPK. Hal tersebut juga dipertegas pada BAB V Perkom No.2/2010, dimana jika dalam persekongkolan tender terdapat keterlibatan pegawai negeri/penyelenggara negara, KPPU dapat menyampaikan persekongkolan tersebut kepada atasan pegawai yang bersangkutan ataupun kepada lembaga penegakan hukum seperti Kejaksaan dan KPK." ${ }^{26}$ Ketentuan tersebut mengisyaratkan bahwa persekongkolan tender yang menjadi lingkup kewenangan KPPU, juga dapat dikaitkan dengan tindak pidana korupsi yang menjadi kewenangan KPK. KPPU akan memproses pelaku persekongkolan, lalu terhadap korporasinya KPPU dapat menjatuhkan sanksi administrasi. Tetapi jika di dalamnya terdapat pejabat pemerintah/penyelenggara negara yang mengatur proses tender ataupun menerima suap/gratifikasi, KPK dapat menindak para pelakunya ke dalam sistem peradilan tindak pidana korupsi. Berikut ini perbandingan kewenangan penegakan hukum KPPU dan KPK dalam penegakan hukum di pengadaan barang dan jasa pemerintah:

Tabel 1. Perbandingan Kewenangan KPPU dan KPK dalam Penegakan Hukum di Pengadaan Barang dan Jasa Pemerintah

\begin{tabular}{|c|c|}
\hline $\begin{array}{c}\text { Komisi Pengawas Persaingan Usaha } \\
\text { (KPPU) }\end{array}$ & $\begin{array}{c}\text { Komisi Pemberantasan Korupsi } \\
\text { (KPK) }\end{array}$ \\
\hline $\begin{array}{l}\text { Dasar Hukum: } \\
\text { 1. UU No.5/1999 (UU Anti Monopoli) } \\
\text { 2. Perkom No.2/2010 (Pedoman Pasal 22) } \\
\text { 3. Perkom No.1/2019 (Tata Cara } \\
\text { Penanganan Perkara oleh KPPU) }\end{array}$ & $\begin{array}{l}\text { Dasar Hukum: } \\
\text { 1. UU No.31/1999 jo. UU No.20/2001 } \\
\text { (UU Tipikor) } \\
\text { 2. UU No.30/2002 jo. UU No.19/2019 } \\
\text { (UU KPK) } \\
\text { 3. UU No.8/1981 (KUHAP) }\end{array}$ \\
\hline \begin{tabular}{lcr} 
Dalam perkara & \multicolumn{2}{c}{ persekongkolan di } \\
pengadaan barang dan jasa pemerintah, & pem \\
ruang lingkup & KPPU & mencakup \\
Persekongkolan & \multicolumn{2}{c}{ Horizontal, } \\
Persekongkolan & Vertikal \\
Persekongkolan Gabungan (Horizontal \& \\
Vertikal)
\end{tabular} & $\begin{array}{l}\text { Dalam perkara persekongkolan di } \\
\text { pengadaan barang dan jasa pemerintah, } \\
\text { ruang lingkup KPK hanya mencakup } \\
\text { Persekongkolan } \\
\text { Persekongkolan Gabungan (Horizontal \& } \\
\text { Vertikal) }\end{array}$ \\
\hline $\begin{array}{l}\text { Berwenang menindak pelaku usaha yang } \\
\text { melakukan Persekongkolan Tender dalam } \\
\text { pengadaan barang dan jasa pemerintah }\end{array}$ & $\begin{array}{l}\text { Berwenang menindak pelaku (baik dari } \\
\text { pelaku usaha maupun penyelenggara } \\
\text { negara/pegawai negeri) yang melakukan } \\
\text { tindak pidana korupsi dalam pengadaan } \\
\text { barang dan jasa pemerintah }\end{array}$ \\
\hline $\begin{array}{l}\text { Tidak dapat menjatuhkan sanksi kepada } \\
\text { panitia tender (penyelenggara negara/ } \\
\text { pegawai negeri), hanya dapat dijadikan } \\
\text { sebagai Terlapor. Sanksi hanya dapat } \\
\text { dijatuhkan oleh atasan dari pegawai negeri } \\
\text { yang dimaksud }\end{array}$ & $\begin{array}{l}\text { Dapat menindak panitia tender karena } \\
\text { merupakan penyelenggara negara/pegawai } \\
\text { negeri sebagaimana diatur dalam Pasal } 11 \\
\text { UU KPK. Namun, penjatuhan sanksi tetap } \\
\text { menjadi kewenangan Pengadilan Tipikor }\end{array}$ \\
\hline
\end{tabular}

\footnotetext{
${ }^{25}$ Erlangga Adikusumah, "KPK, Korupsi dan Persekongkolan Tender" (Materi disampaikan pada acara Diskusi Publik Bersama KPPU \& KPK: Menyikapi Permasalahan dan Penyelesaian Hukum dalam Persekongkolan Tender, Bandar Lampung, 25 Februari 2020).

${ }^{26}$ Peraturan Komisi Pengawas Persaingan Usaha No. 2 Tahun 2010 tentang Pedoman Pasal 22 tentang Larangan Persekongkolan Dalam Tender, 18.
} 


\begin{tabular}{|l|l|}
\hline $\begin{array}{l}\text { Sanksi yang dijatuhkan berupa sanksi } \\
\text { administratif }\end{array}$ & $\begin{array}{l}\text { Sanksi yang dapat dikenakan berupa sanksi } \\
\text { perampasan kemerdekaan (pidana penjara } \\
\text { dan/atau pidana kurungan) serta pidana } \\
\text { denda }\end{array}$ \\
\hline $\begin{array}{l}\text { Persekongkolan tender diatur dalam Pasal } \\
\text { 22 dan penjatuhan sanksinya mengacu pada } \\
\text { Pasal 47, Pasal 48 ayat (2) dan Pasal 49 UU } \\
\text { No.5/1999 }\end{array}$ & $\begin{array}{l}\text { Penjatuhan sanksi dapat mengacu pada } \\
\text { Pasal 2, Pasal 3, Pasal 5, Pasal 7, Pasal 11, } \\
\text { UU No.20/2001 }\end{array}$ \\
\hline
\end{tabular}

Dapat dilihat bahwa KPPU dan KPK memiliki ruang lingkup dan kewenangannya masing-masing dalam melakukan penegakan hukum terhadap pelaku penyimpangan dalam pengadaan barang dan jasa pemerintah, khususnya terkait perkara persekongkolan tender. Namun, keduanya juga memiliki kerjasama dalam hal pengawasan dan penegakan hukum dalam pengadaan barang dan jasa pemerintah. Kerja sama tersebut tertuang dalam Memorandum of Understanding (MoU) antara KPPU dan KPK. ${ }^{27} \mathrm{MoU}$ tersebut di dalamnya berisi kerjasama mengenai pertukaran informasi dan data terkait dengan sistem utilitas nasional, pemberian keterangan sebagai narasumber atau ahli baik dari segi perdataan atau pertukaran informasi kasus KPPU yang masuk kewenangan KPK maupun sebaliknya. ${ }^{28}$ KPPU dapat melakukan investigasi terhadap pengadaan yang terindikasi persekongkolan tender, apabila ditemukan persekongkolan vertikal atau gabungan (ada keterlibatan panitia tender), hal tersebut dapat berpotensi mengarah ke praktik korupsi. KPPU dapat melakukan pertukaran informasi kepada KPK ataupun instansi penegak hukum tindak pidana korupsi lainnya. Putusan KPPU yang inkracht juga dapat dijadikan bukti permulaan yang cukup bagi penyidik. Sebaliknya, jika KPK dapat mengidentifikasi proses pengadaan yang terindikasi persekongkolan dalam tender, KPK juga dapat melakukan pertukaran informasi kepada KPPU.

KPPU dan KPK merupakan lembaga pemberantas praktik-praktik curang dalam pengadaan barang dan jasa pemerintah. Melihat urgensi dari suatu pengadaan barang dan jasa sangat berpengaruh dalam pembangunan negara. Salah satu kasus dalam pengadaan barang dan jasa pemerintah yang terlebih dahulu diusut oleh KPPU sebagai perkara persekongkolan tender, lalu kemudian kasus tersebut juga diusut oleh KPK karena terdapat tindak pidana korupsi dalam pengadaannya, yakni kasus Pengadaan E-KTP oleh Direktorat Jenderal Kependudukan dan Pencatatan Sipil (Dirjen Dukcapil) Kementerian Dalam Negeri (Kemendagri) Tahun Anggaran 2011 dan Tahun Anggaran 2012. Sejak awal pengadaan, proyek E-KTP ini memang sudah bermasalah, terdapat politik anggaran dan 'kongkalingkong' oleh orang-orang dari DPR, Kementerian dan BUMN/Swasta yang terkait. Pengadaan juga telah diatur siapa yang menang dan siapa saja yang menerima keuntungan. Hal tersebut dibuat sedemikian rupa seolah-olah semua syarat terpenuhi. ${ }^{29}$ Pada proses penegakan hukum kasus Pengadaan E-KTP, KPPU terlebih dahulu mengusut kasus tersebut dan menemukan adanya persekongkolan tender gabungan (horizontal vertikal) antara pelaku usaha dengan panitia tendernya. Kasus ini merupakan salah satu kasus yang pertama kali ditangani KPPU lalu kemudian dilimpahkan ke KPK. Dimana KPK kemudian mengusut para pelaku dalam kasus tersebut dengan dakwaan memperkaya diri sendiri, orang lain, dan korporasi dalam proyek E-KTP sehingga membuat negara rugi Rp. 2,3 triliun.

\footnotetext{
${ }^{27}$ https://www.kppu.go.id/id/blog/2014/07/kppu-kpk-sepakat-kerjasama-penegakan-hukum-persaingan/, diakses pada 14 Mei 2020, 01.32 WIB

${ }^{28}$ Hasil Kuisioner dengan Rosanna Sarita selaku Investigator Madya (Penugasan pada Bagian Kepaniteraan) di KPPU pada 29 Mei 2020

${ }^{29}$ Hasil Wawancara dengan Mohamad Nur Aziz, Kepala Satuan Tugas (Kasatgas) 16 Penuntutan di KPK pada 12 Mei 2020 pukul 09.02 WIB
} 


\section{Faktor-faktor yang mempengaruhi Penegakan Hukum dalam Pengadaan Barang dan Jasa Pemerintah yang dilakukan oleh KPPU dan KPK}

Penegakan hukum pidana merupakan suatu proses guna mewujudkan keinginan hukum yaitu pikiran-pikiran badan pembuat undang-undang yang dirumuskan dalam peraturan hukum menjadi kenyataan. ${ }^{30}$ Penegakan hukum pidana pidana yang rasional terdiri dari tiga tahap, yakni: ${ }^{31}$

a. Tahap Formulasi, adalah tahap penegakan hukum pidana in abstracto oleh badan pembentuk undang-undang.

b. Tahap Aplikasi, adalah tahap penegakan hukum pidana (penerapan hukum pidana) oleh aparat-aparat penegak hukum yakni kepolisian, kejaksaan hingga pengadilan.

c. Tahap Eksekusi, adalah tahap penegakan (pelaksanaan) hukum pidana secara kongkret oleh aparat pelaksana pidana.

Berbeda dengan tahap kesatu yang merupakan kegiatan pembentukan undang-undang, tahap kedua dan ketiga merupakan tahapan kegiatan penegakan hukum (law enforcement). Dalam upaya penegakan hukum, terdapat faktor-faktor yang mempengaruhi penegakan hukum itu sendiri. Faktor-faktor yang mempengaruhi penegakan hukum diantaranya adalah: ${ }^{32}$

a. Faktor Peraturan Perundang-undangan (substansi hukum)

b. Faktor Penegak Hukum

c. Faktor Sarana \& Fasilitas

d. Faktor Masyarakat

e. Faktor Kebudayaan

Pengadaan barang dan jasa pemerintah sejatinya merupakan salah satu alat untuk menggerakan roda perekenomian dalam rangka meningkatkan perekonomian nasional guna terciptanya kesejahteraan rakyat dan peningkatan mutu sumber daya manusia. ${ }^{33}$ Pengadaan barang dan jasa juga dilaksanakan dengan tujuan untuk mencapai keadilan dan kesejahteraan bagi masyarakat. Namun pada pelaksanaannya, banyak menimbulkan permasalahan hukum dan menyebabkan kerugian negara yang tidak sedikit. ${ }^{34}$ Sampai saat ini masih banyak terjadi penyimpangan disetiap tahapan-tahapan dalam pengadaan barang dan jasa pemerintah.

Tahapan kegiatan pengadaan barang dan jasa secara umum dapat dikelompokan menjadi 4 (empat) tahap, yaitu: ${ }^{35}$

a. Tahap persiapan;

b. Tahap proses pengadaan;

c. Tahap penyusunan kontrak; dan

d. Tahap pelaksanaan kontrak.

Tahapan-tahapan tersebut menunjukan bahwa dalam kegiatan pengadaan barang dan jasa pemerintah terdapat proses yang tidak singkat, terdapat perencanaan hingga selesainya

\footnotetext{
${ }^{30}$ Soerjono Soekanto, Faktor-Faktor Yang Memepengaruhi Penegakan Hukum, (Jakarta: Raja Grafindo Persada, 1983), 5

${ }^{31}$ Roeslan Saleh, Pembinaan Cita Hukum Dan Asas-Asas Hukum Nasional, (Jakarta: Karya Dunia Piker, 1996), 15.

${ }^{32}$ Muladi dan Barda Nawawi Arief, Bunga Rampai Kebijakan Hukum Pidana, (Bandung: Citra Aditiya Bakti, 2009), 173

${ }^{33}$ Rendra Alfonso Sitorus, Syafruddin Kalo, Mahmul Siregar, M. Ekaputra, "TINJAUAN YURIDIS PERTANGGUNGJAWABAN PIDANA KORUPSI PENGADAAN ALAT KESEHATAN RSUD SIDIKALANG: STUDI PUTUSAN PENGADILAN NEGERI MEDAN NO. 61/PID.SUS-TPK/2016/PNMDN", USU Law Journal 7, no. 7 (2019): 80-91, 81.

${ }^{34}$ Beridiansyah, "ANALISIS YURIDIS TERHADAP PENGADAAN BARANG DAN JASA GUNA MENCEGAH KORUPSI”, Integritas 3, no. 2 (2017): 79-103, 84, DOI: 10.32697/integritas.v3i2.103.

${ }^{35}$ Muhammad Rezza Kurniawan dan Pujiyono, "MODUS OPERANDI KORUPSI PENGADAAN BARANG DAN JASA PEMERINTAH OLEH PNS" Jurnal Law Reform 14, no. 1 (2018): 115-131, 119, DOI: 10.14710/lr.v14i1.20241.
} 
seluruh proses kegiatan memperoleh barang atau jasa. ${ }^{36}$ Di setiap tahapan-tahapan pengadaan tersebut, terdapat titik rawan penyimpangan diantaranya terdapat mark up, pengaturan/rekayasa pemenang tender hingga menimbulkan praktik-praktik KKN yang dapat merugikan negara. ${ }^{37}$ Penyimpang-penyimpangan tersebut dapat teridentifikasi dari adanya praktik persekongkolan tender dan tindak pidana korupsi. Persekongkolan tender merupakan bentuk kerja sama baik yang dilakukan oleh sesama pelaku usaha maupun dengan panitia tender untuk menciptakan pengaturan dan persaingan semu dalam proses tender/pelelangan. Sementara itu, persekongkolan tender dalam proyek pemerintah juga menimbulkan praktikpraktik koruptif. Salah satunya seperti suap, gratifikasi, penyalahgunaan wewenang, perbuatan curang dan sebagainya, sehingga perbuatan-perbuatan tersebut dapat dikategorikan sebagai tindak pidana korupsi.

Upaya aparat penegak hukum seperti KPPU dan KPK dalam mengatasi permasalahan dalam pengadaan barang dan jasa pemerintah masih terus menerus dilakukan. Namun upaya tersebut tidak berbanding lurus dengan realitas yang dihadapi dimana masih banyak kasuskasus persekongkolan tender dan tindak pidana korupsi yang terjadi di dalam pengadaan barang dan jasa pemerintah. Upaya tersebut juga tidak terlepas karena terdapat dari faktorfaktor yang mempengaruhi penegakan hukumnya itu sendiri. Terdapat faktor-faktor yang mempengaruhi proses penegakan hukum yang dilakukan oleh KPPU dan KPK dalam mengatasi permasalahan dalam pengadaan barang dan jasa pemerintah, diantaranya adalah:

\section{a. Faktor Peraturan Perundang-undangan (subtansi hukum)}

Proses pemeriksaan yang dilakukan KPPU memang harus dilakukan dengan serangkaian kegiatan. Namun terdapat berbagai macam kendala yang timbul antara lain terkait dengan penggeledahan, pemanggilan para pihak, pembuktian dan eksekusi putusan. KPPU memang memiliki kewenangan untuk melakukan penelitian dan penyidikan, namun KPPU tidak berwenang melakukan penggeledahan terhadap pelaku usaha yang terindikasi melakukan persekongkolan. Selain itu KPPU juga sering terkendala dengan kerahasiaan perusahaan sehingga membutuhkan waktu untuk dapat membuktikan terjadinya pelanggaran terhadap UU Anti Monopoli. Kemudian, KPPU juga kesulitan terhadap pemanggilan para pihak dimana KPPU tidak dapat memaksa kehadiran para pihak maupun para saksi. Adanya pembatasan terhadap alat bukti dan juga kekuatan mengikat dari putusan KPPU menjadi sebuah problematika. Hal tersebut membuat KPPU membuktikan terjadinya pelanggaran persaingan usaha tidaklah gampang. Apalagi peraturan yang berkaitan dengan tender pemerintah yang selalu berubah seiring dengan pergantian pemerintahan. KPPU seharusnya memiliki kewenangan-kewenangan tersebut seperti lembaga penegak hukum lainnya agar dapat memudahkan proses pembuktian dalam menegakan hukum persaingan usaha. Seperti halnya KPK, hampir kewenangan-kewenangan tersebut dimiliki oleh KPK (kecuali mengenai eksekusi putusan) sehingga dapat memudahkan proses pembuktian tindak pidana korupsi. Walaupun begitu, tetap saja KPK juga memiliki kelemahan dalam melakukan penegakan hukum. Dimana dalam UU KPK yang terbaru (UU No.19/2019), upaya paksa seperti penyitaan dan penggeledahan serta tindakan penyadapan yang saat ini harus melalui izin dewan pengawas.

Selain itu, KPPU juga tidak memiliki wewenang dalam menjatuhkan sanksi kepada pihak lain selain dari unsur pelaku usaha, seperti panitia tender/lelang. Hal tersebut memperlihatkan

\footnotetext{
${ }^{36}$ Sabrina Dyah Nayabarani, "MEMBANGUN TRANSPARANSI PENGADAAN BARANG DAN JASA MELALUI PENINGKATAN PERAN ICT DALAM MEREDUKSI KORUPSI", Jurnal Hukum \& Pembangunan 47, no. 4 (2017): 477-496, 483, DOI: 10.21143/.vol47.no4.1586.

${ }^{37}$ Musa Darwin Pane, "ASPEK HUKUM PENGADAAN BARANG DAN JASA PEMERINTAH SUATU TINJAUAN YURIDIS PERATURAN PENGADAAN BARANG DAN JASA PEMERINTAH", Jurnal Media Hukum 2, no. 2 (2017): 147-155, 152, DOI: 10.18196/ jmh.2017.0090.147- 155.
} 
KPPU memiliki ketimpangan yang sangat kontras dalam menegakan hukuman bagi para pelaku persekongkolan. Oleh karenanya, banyak yang mengatakan lembaga KPPU ini seperti 'Macan Ompong'. ${ }^{38}$ Problematika mengenai eksekusi putusan KPPU juga menjadi hambatan dalam penegakan hukum persaingan usaha. Dimana semua putusan yang dikeluarkan oleh KPPU haruslah mendapat penetapan eksekusi oleh Pengadilan Negeri (PN). Belum lagi jika terdapat keberatan dari pelaku usaha, terhadap putusan KPPU tersebut PN dapat menguatkan atau membatalkan putusan berdasarkan Pasal 44 UU Anti Monopoli. ${ }^{39}$

\section{b. Faktor Penegak Hukum}

KPPU memang memiliki fungsi penegakan hukum khususnya hukum persaingan usaha, akan tetapi KPPU bukanlah lembaga peradilan khusus persaingan usaha. Kedudukan KPPU lebih merupakan lembaga administratif dan sanksi yang dijatuhkan pun merupakan sanksi administratif. Hal tersebut sangat berimplikasi pada proses penegakan hukum karena terdapat ketidakpastian kekuatan menghukum dari KPPU baik hukuman pidana maupun perdata. Di lain sisi, terdapat KPK yang memiliki wewenang dalam penegakan hukum pidana terhadap pemberantasan tindak pidana korupsi. Namun sampai sekarang masih saja terdapat pihakpihak yang ingin melemahkan lembaga tersebut dengan melakukan berbagai cara karena dianggap telah 'mengganggu' budaya korupsi di negeri ini.

KPPU dan KPK memang telah memiliki kerja sama dalam hal pengawasan dan penegakan hukum dalam pengadaan barang dan jasa pemerintah. Namun sayangnya, dalam kerja sama tersebut tidak ada pembuatan daftar perkara yang pernah ditangani bersama antara KPPU dan KPK sehingga informasi dan data perkara terlihat masih minim. Koordinasi antar keduanya juga seharusnya menjadi trigger mechanism bagi aparat penegak hukum lainnya. Trigger mechanism sendiri berarti mendorong atau sebagai stimulus agar upaya penegakan hukum menjadi lebih efektif dan efisien. Selain KPPU dan KPK, sebenarnya dalam mengatasi permasalahan pengadaan barang dan jasa pemerintah juga menjadi wewenang dari Kepolisian dan Kejaksaan. Namun, kedua lembaga tersebut kerap dinilai kurang konsisten dan tidak tegas dalam melakukan penegakan hukum terhadap proyek pemerintah, terutama di proyek pemerintah daerah. Banyak kasus-kasus korupsi dalam pengadaan barang dan jasa di pemerintah daerah yang melibatkan oknum-oknum aparat penegak hukum dari Kepolisian ataupun Kejaksaan. Oknum-oknum dari kedua instansi tersebut kerap menerima sejumlah uang fee (gratifikasi) baik dari pelaku usaha maupun pejabat pengadaan agar praktik kotor yang dilakukan dalam pengadaan tersebut berjalan lancar. Walaupun begitu, Kepolisian dan Kejaksaan juga sering menangani kasus-kasus korupsi di pengadaan barang dan jasa pemerintah. Integritas moral dari aparat penegak hukum sendiri sangat mempengaruhi jalannya proses penegakan hukum di Indonesia. Sementara itu, KPK juga memiliki kerjasama dengan Badan Pemeriksa Keuangan (BPK) maupun Badan Pengawas Keuangan dan Pembangunan (BPKP) dalam melakukan audit kerugian negara. Proses audit sendiri biasanya memakan waktu yang lama sehingga hal tersebut juga dapat mempengaruhi proses penegakan hukum tindak pidana korupsi.

\section{c. Faktor Sarana dan Fasilitas}

Hampir di seluruh daerah memiliki instansi penegak hukum, namun untuk KPPU sendiri kantor wilayahnya (kanwil) cukup terbatas. Contohnya di pulau Sumatera, KPPU hanya memiliki dua kanwil yang berada di Provinsi Sumatera Utara dan Provinsi Lampung. Selain itu, KPK juga sekarang tidak dapat membentuk perwakilan di daerah karena kewenangan

\footnotetext{
${ }^{38}$ https://inilah.com/news/253014 2/19-tahun-kppu-tetap-saja-macan-ompong, diakses pada 4 Mei 2020.

39 Rai Mantili, Hazar Kusmayanti dan Anita Afriana, "PROBLEMATIKA PENEGAKAN HUKUM PERSAINGAN USAHA DI INDONESIA DALAM RANGKA MENCIPTAKAN KEPASTIAN HUKUM”, Padjajaran Jurnal Ilmu Hukum 3, no. 1 (2016): 116-132, 130, DOI: 10.22304/pjih.v3n1.a7.
} 
tersebut telah dihapus dalam UU KPK yang baru. Hal tersebut tentunya membuat upaya penegakan hukum di daerah-daerah terkesan lebih diminimalisir.

\section{d. Faktor Masyarakat}

Banyak pelaku usaha yang berebut mendapatkan pekerjaan melalui seleksi yang tidak benar (tidak tranpsparan dan diskriminasi). Mereka menyuap pejabat pengadaan agar perusahaan mereka diloloskan. Adapun tim-tim sukses dari seorang kepala daerah yang terpilih sering meminta-minta jatah proyek. Hal tersebut membuat sebuah kebiasaan yang buruk dari setiap proyek-proyek pengadaan barang dan jasa pemerintah, khususnya proyek di daerah. Keberadaan tokoh-tokoh besar juga mempengaruhi proses penegakan hukum. Apalagi melihat bentuk politik di Indonesia yang sering kali mempengaruhi proses penegakan hukum tindak pidana korupsi. Tidak sedikit penegakan hukum tindak pidana korupsi yang kerap melibatkan penyelenggara negara dan pejabat negara terkesan lambat karena sulitnya mencari bukti-bukti dan petunjuk. Media pun juga kadangkala juga dapat mengganggu mempengaruhi proses penegakan hukum. Walaupun karena media bisa menjadi jembatan informasi bagi masyarakat, kadangkala isu-isu yang tak sedap dapat menyita fokus para aparat penegak hukum. Masyarakat juga seharusnya dapat menjadi pelapor aktif apabila menemukan adanya praktik korupsi, kolusi dan nepotisme sehingga dapat memudahkan proses penegakan hukum dan bukan malah ikut menjadi bagian dari praktik busuk tersebut.

\section{e. Faktor Kebudayaan}

Kebiasaan perilaku koruptif dengan kualitas moral yang rendah telah menjadi endemik di negeri ini, ditambah penerapan prinsip antikorupsi di suatu lingkungan hanya dilakukan sebatas formalitas. Karakter bangsa yang sudah biasa menganggap bentuk-bentuk pemberian baik berupa hadiah ataupun imbalan seperti upeti/uang fee (suap dan gratifikasi) dalam pengadaan barang dan jasa menjadi hal yang lumrah terjadi. Kemudian, kurang kuatnya penerapan budaya malu di kalangan para pejabat negara ditambah dengan pendapatan yang dianggap kurang memadai, dijadikan alasan oleh penyelenggara negara tersebut untuk melakukan tindakan koruptif pada kegiatan pengadaan barang dan jasa pemerintah. Sementara itu, masyarakat juga yang sudah banyak merasa lelah dan pada akhirnya apatis terhadap penegakan hukum yang kurang tegas terhadap para pelaku koruptor. Penegakan hukum terhadap persekongkolan tender dan tindak pidana korupsi yang timbul dari pengadaan barang dan jasa haruslah dilaksanakan secara tegas dan tanpa diskriminasi serta harus dilakukan secara terus-menerus, sehingga diharapkan adanya efek jera agar tidak mengulangi perbuatan tersebut. Tumbuhnya kesadaran untuk berani mengatakan tidak kepada segala bentuk penyelewengan dalam pelaksanaan dan penggunaan anggaran akan berdampak tumbuhnya kepercayaan (trust) dari bangsa lain kepada Indonesia untuk mewujudkan Indonesia yang sejahtera, tertib dan patuh hukum sebagai syarat good governance and clean governance.

\section{Kesimpulan}

Upaya penegakan hukum dalam pengadaan barang dan jasa pemerintah yang dilakukan oleh KPPU terhadap perkara persekongkolan tender berdasarkan UU No.5/1999 (UU Anti Monopoli), Perkom No.1/2019 dan Perkom No.2/2010 (Pedoman Pasal 22). Sedangkan penegakan hukum dalam pengadaan barang dan jasa pemerintah dilakukan oleh KPK terhadap perkara tindak pidana korupsi berdasarkan UU No.31/1999 jo. UU No.20/2001 (UU Tipikor), UU No.30/2002 jo. UU No.19/2019 (UU KPK) dan KUHAP. Kedua lembaga tersebut memang memiliki ruang lingkup dan kewenangannya masing-masing, namun keduanya juga memiliki kerjasama dalam hal pengawasan dan penegakan hukum dalam pengadaan barang dan jasa pemerintah yang tertuang dalam Memorandum of Understanding 
(MoU) antara KPPU dan KPK. Kasus-kasus persekongkolan tender yang diputus KPPU (yang terindikasi tindak pidana korupsi) dapat ditindaklanjuti oleh KPK. Begitu pun sebaliknya, dimana kasus-kasus korupsi di sektor pengadaan barang dan jasa pemerintah yang ditangani KPK juga dapat diusut juga oleh KPPU.

Terdapat faktor-faktor yang mempengaruhi penegakan hukum dalam pengadaan barang dan jasa pemerintah yang dilakukan oleh KPPU dan KPK, antara lain faktor peraturan perundang-undangan (substansi hukum), faktor penegak hukum, faktor sarana/fasilitas, faktor masyarakat dan faktor kebudayaan. KPPU memiliki kendala terkait kewenangan dalam penggeledahan, pemanggilan para pihak, pembuktian dan eksekusi putusan, selain itu KPPU juga tidak dapat menjatuhkan sanksi bagi panitia tender dalam perkara persekongkolan tender. Sementara itu, KPK juga mengalami kesulitan terkait upaya paksa seperti penyitaan dan penggeledahan serta tindakan penyadapan yang saat ini harus melalui izin dewan pengawas. KPK juga saat ini tidak dapat membuka kantor perwakilan di daerah karena dalam UU terbaru kewenangan tersebut telah dihapus. Kemampuan dan integritas moral dari para penegak hukum, serta kerjasama antar lembaga sangat mempengaruhi proses penegakan hukum di Indonesia. Kemudian, praktik budaya korupsi yang sudah dianggap lazim dapat diminimalisir apabila masyarakat lebih pro-aktif dalam melaporkan dugaan praktik curang dalam pengadaan barang dan jasa pemerintah terutama di daerah-daerah, sehingga laporan tersebut dapat memudahkan aparat penegak hukum dalam menindak para pelakunya.

\section{Saran}

Diharapkan pemerintah dan pembuat undang-undang dapat memperbaharui hukum terutama terkait kewenangan KPPU mengenai upaya penggeledahan, pemanggilan saksi dan pembuktian agar dapat memudahkan proses penegakan hukum persaingan usaha. Selain itu, diharapkan agar ketentuan mengenai kantor perwakilan KPK di daerah dapat dikembalikan. KPPU dan KPK dapat meningkatkan kerja sama dalam menindak para pelaku kejahatan di bidang pengadaan barang dan jasa pemerintah. Keduanya juga dapat membuat daftar perkara yang pernah ditangani bersama dan dipublikasi secara terbuka agar dapat bermanfaat dan berguna bagi para praktisi, akademisi/pemerhati hukum serta masyarakat umum. Diharapkan kepada semua penegak hukum dapat melakukan tugasnya secara profesional dan menjunjung integritas moral yang tinggi, agar apa yang diharapkan oleh masyarakat terhadap penegak hukum dapat terlaksana dengan baik.

\section{A. Jurnal}

\section{DAFTAR PUSTAKA}

Asmah. "PENERAPAN SANKSI DENDA TERHADAP KASUS PERSEKONGKOLAN TENDER JALAN NASIONAL”, Jurnal Yudisial12, no. 2, 2019: 197-214, http://dx.doi.org/10.29123/jy.v12i2.280.

Beridiansyah. "ANALISIS YURIDIS TERHADAP PENGADAAN BARANG DAN JASA GUNA MENCEGAH KORUPSI”, Integritas 3, no. 2, 2017: 79-103, https://doi.org/10.32697/integritas.v3i2.103.

Bukido, Rosdalina., Bamatraf, Laila F. "PERANAN KOMISI PENGAWAS PERSAIANGAN USAHA (KPPU) DALAM MENEGAKAN UNDANG-UNDANG NOMOR 5 TAHUN 1999 TENTANG LARANGAN PRAKTIK MONOPOLI DAN PERSAINGAN USAHA TIDAK SEHAT", Jurnal Ilmiah Al-Syir'ah 15, no. 1, 2017: 56-73.

Habibi, Muhammad. "INDEPENDENSI KEWENANGAN KOMISI PEMBERANTASAN KORUPSI PASCA PERUBAHAN UNDANG-UNDANG NOMOR 30 TAHUN 2002 TENTANG KOMISI PEMBERANTASAN KORUPSI", Jurnal Cepalo 4, no. 1, 2020: 41-51, https://doi.org/10.25041/cepalo.v4no1.1962. 
Haryati, Dwi, Anugrah Anditya., Wibowo, Richo Andi. "PELAKSANAAN PENGADAAN BARANG/JASA SECARA ELEKTRONIK (E-PROCUREMENT) PADA PEMERINTAH KOTA YOGYAKARTA”, Mimbar Hukum 23, no. 2, 2011: 328-342, https://doi.org/10.22146/jmh.16192.

Indriana, Yayan. "PENGEMBALIAN GANTI RUGI KEUANGAN NEGARA PADA PERKARA TINDAK PIDANA KORUPSI", Jurnal Cepalo 2, no. 2, 2018: 121-128, https://doi.org/10.25041/cepalo.v2no2.1769.

Kurniawan, Muhammad Rezza., Pujiyono. "MODUS OPERANDI KORUPSI PENGADAAN BARANG DAN JASA PEMERINTAH OLEH PNS”. Jurnal Law Reform 14, no. 1, 2018: 115-131, https://doi.org/10.14710/lr.v14i1.20241.

Mahardika., Wijaya, Firman. "KAJIAN YURIDIS FUNGSI PENCEGAHAN KOMISI PEMBERANTASAN KORUPSI DALAM PEMBERANTASAN TINDAK PIDANA KORUPSI PENGADAAN BARANG DAN JASA SECARA ELEKTRONIK DI PROVINSI DKI JAKARTA”. Jurnal Hukum Adigama 1, no. 2, 2018: 1-25, 6, http://dx.doi.org/10.24912/adigama.v1i2.2925.

Mantili, Rai., Kusmayanti, Hazar., Afriana, Anita. "PROBLEMATIKA PENEGAKAN HUKUM PERSAINGAN USAHA DI INDONESIA DALAM RANGKA MENCIPTAKAN KEPASTIAN HUKUM", Padjajaran Jurnal Ilmu Hukum 3, no. 1, 2016: 116-132, https://doi.org/10.22304/pjih.v3n1.a7.

Mulyono, Purnomo Edy. "ANALISIS PELAKSANAAN PENGADAAN BARANG/JASA SECARA ELEKTRONIK PADA PEMERINTAH KABUPATEN GRESIK”. Airlangga Development Journal 1, no. 1, 2017: 32-42, http://dx.doi.org/10.20473/adj.v1i1.18010.

Nayabarani, Sabrina Dyah. "MEMBANGUN TRANSPARANSI PENGADAAN BARANG DAN JASA MELALUI PENINGKATAN PERAN ICT DALAM MEREDUKSI KORUPSI". Jurnal Hukum \& Pembangunan 47, no. 4, 2017: 477-496, 483, http://dx.doi.org/10.21143/.vol47.no4.1586.

Pane, Musa Darwin. "ASPEK HUKUM PENGADAAN BARANG DAN JASA PEMERINTAH SUATU TINJAUAN YURIDIS PERATURAN PENGADAAN BARANG DAN JASA PEMERINTAH”, Jurnal Media Hukum 2, no. 2, 2017: 147-155, 10.18196/ jmh.2017.0090.147- 155.

Sitorus, Rendra Alfonso, Syafruddin Kalo, Mahmul Siregar, M. Ekaputra. "TINJAUAN YURIDIS PERTANGGUNGJAWABAN PIDANA KORUPSI PENGADAAN ALAT KESEHATAN RSUD SIDIKALANG: STUDI PUTUSAN PENGADILAN NEGERI MEDAN NO. 61/PID.SUS-TPK/2016/PN-MDN", USU Law Journal 7, no. 7, 2019: 8091.

Wisny. "PENERAPAN SANKSI ADMINISTRATIF OLEH KOMISI PENGAWAS PERSAINGAN USAHA (KPPU) TERHADAP PELAKU USAHA YANG MELAKUKAN PERSEKONGKOLAN DALAM TENDER". Pakuan Law Review 1, no. 2, 2015: 359-381, 10.33751/palar.v2i2.941.

Zihaningrum, Apectriyas., Kholil, Munawar. "PENEGAKAN HUKUM PERSEKONGKOLAN TENDER BERDASARKAN UNDANG-UNDANG NOMOR 5 TAHUN 1999 TENTANG LARANGAN PRAKTIK MONOPOLI DAN PERSAINGAN USAHA TIDAK SEHAT." Privat Law 4, no. 1, 2016:107-116.

\section{B. Buku}

Deputi Penelitian dan Pengembangan KPK. Laporan Hasil: Kajian Pencegahan Korupsi Pada Pengadaan Barang dan Jasa Pemerintah. Jakarta: KPK, 2014.

Lubis, Andi Fahmi. et al., Hukum Persaingan Usaha, ed.2, Jakarta: KPPU, 2017.

Muladi., Arief, Barda Nawawi. Bunga Rampai Kebijakan Hukum Pidana, Bandung: Citra Aditiya Bakti, 2009. 
Murniati, Rilda. Hukum Persaingan Usaha, Bandar Lampung: Justice Publisher, 2014.

Pusat Edukasi Antikorupsi (KPK). Modul Materi Tindak Pidana Korupsi. Jakarta: Komisi Pemberantasan Korupsi, 2020.

Raharjo, Satjipto. Penegakan Hukum Sebagai Tinjauan Sosiologis. Yogyakarta: Genta Publishing, 2009.

Saleh, Roeslan. Pembinaan Cita Hukum Dan Asas-Asas Hukum Nasional, Jakarta: Karya Dunia Piker, 1996.

Soekanto, Soerjono. Faktor-Faktor Yang Mempengaruhi Penegakan Hukum, Jakarta: Raja Grafindo Persada, 1983.

\section{Internet}

https://jdih.lkpp.go.id/news/14/siaran-pers-peraturan-presiden-nomor-16-tahun-2018-tentangpengadaan-barangjasa-pemerintah, diakses pada 31 Mei 2020, 12.36 WIB.

https://news.detik.com/berita/d-3885311/icw-korupsi-pengadaan-barang-2017-meningkat, diakses pada 31 Mei 2020, Pukul 12.50 WIB.

https://news.detik.com/berita/d-4748948/uu-kpk-baru-berlaku-ini-pasal-pasal-yang-mulaiaktif diakses pada Selasa, 14 April 2020, 15.33 WIB.

https://www.kppu.go.id/id/blog/2014/07/kppu-kpk-sepakat-kerjasama-penegakan-hukumpersaingan/, diakses pada 14 Mei 2020, 01.32 WIB.

https://inilah.com/news/253014 2/19-tahun-kppu-tetap-saja-macan-ompong, diakses pada 4 Mei 2020.

http://putusan.kppu.go.id/, diakses pada tanggal 8 September 2020, 19.40 WIB.

\section{Peraturan dan Dokumen}

Adikusumah, Erlangga. "KPK, Korupsi dan Persekongkolan Tender" (Materi disampaikan pada acara Diskusi Publik Bersama KPPU \& KPK: Menyikapi Permasalahan dan Penyelesaian Hukum dalam Persekongkolan Tender, Bandar Lampung, 25 Februari 2020)

Peraturan Komisi Pengawas Persaingan Usaha No. 1 Tahun 2019 tentang Tata Cara Penanganan Perkara Praktik Monopoli dan Persaingan Usaha Tidak Sehat.

Peraturan Komisi Pengawas Persaingan Usaha No. 2 Tahun 2010 tentang Pedoman Pasal 22 tentang Larangan Persekongkolan Dalam Tender

Undang-Undang Republik Indonesia Nomor 19 Tahun 2019 Tentang Perubahan Kedua Atas Undang-Undang Nomor 30 Tahun 2002 Tentang Komisi Pemberantasan Tindak Pidana Korupsi.

UU No. 30 Tahun 2002 tentang Komisi Pemberantasan Korupsi, LN No. 137 Thn. 1999, TLN No. 4250. 
